\title{
Which Families Benefited from the Recent Personal Income Tax Reform in Taiwan: Evidence from the Administrative Data
}

\author{
Joseph Teyu $\mathrm{Chou}^{1}$ (i) $\cdot$ Chien-Hao Fu
}

Accepted: 25 July 2021 / Published online: 14 August 2021

() The Author(s), under exclusive licence to Springer Science+Business Media, LLC, part of Springer Nature 2021

\begin{abstract}
This paper examines the changes in vertical equity across different types of tax filing families during the span of a series of drastic personal income tax reforms in Taiwan. The newly enacted 2016 Taxpayer Rights Protection Act has brought unprecedented challenges to the tax authority's distributional goal and revenue stability. Utilizing the administrative tax return data collected by the Ministry of Finance's Fiscal Information Agency between 2016 and 2018, we show that while the income tax has contributed to improving equality in income distribution, the effects, however, were limited and even declined slightly in recent years. We also found that distributions of tax benefits are generally regressive, especially among itemized and special deductions. It is also shown that the personal exemption and the adjustments of basic living expenses provided comparably more relief to households with dependents than to those claiming no dependents. According to our two-parameter metric encompassing the usage rates and the tax-benefit distributions for each deduction, we found that itemized deductions and special deductions, in general, are regressive. Specifically, we calculate and compare different representative families' tax payments before and after the reform. While the tax reform has helped reduce many tax-filing families' tax liabilities, most tax benefits generated from the expansion of exemptions and deductions would likely be enjoyed by families with higher incomes. In a broader reform-minded context, the analysis cautions the tax authority in Taiwan and equity pursuing policy makers in other countries not to prioritize an overarching short-term equity goal over long-term revenue stabilization. Phasing out or capping some of the itemized deductions such as donations and special deductions related to discretionary purchasing decisions looks to be a promising reform path toward improving equity and restoring revenue stability.
\end{abstract}

Keywords Personal income tax $\cdot$ Exemption $\cdot$ Deductions $\cdot$ Basic living expenses $\cdot$ Administrative data

\section{Introduction}

The personal income tax (PIT) is a critical component of modern tax systems. Among OECD countries, PIT, on average, accounts for about one-fourth of national tax revenue, or

This is one of several papers published together in Journal of Family and Economic Issues on the "Special Issue on Consumer and Family Economic and Financial Issues"

Joseph Teyu Chou

dychou@nccu.edu.tw

Chien-Hao Fu

chienhaofu@gm.ntpu.edu.tw

1 Department of Public Finance, National Chengchi University, Taipei 116, Taiwan

2 Department of Public Finance, National Taipei University, New Taipei City 237, Taiwan close to 8\% of GDP (OECD, 2018). In addition to its importance as a major source of government revenue, it is also regarded as a vital policy tool to achieve equity and other objectives of public interest. As a direct tax, the burden of income tax can be adjusted based on individual and household characteristics. Governments around the world have thus been frequently modifying their regulations to address issues deemed crucial on their political agenda.

Changes in income tax codes, however, could have important implications for society. At the micro-level, income tax modifications could affect a family's disposable income. Therefore, deferral or reduction of tax payments has often been implemented as a tool to provide relief for families under financial stress. The most recent examples come from adjustments of tax policy in response to the coronavirus crisis. Many countries lowered payments, implemented flexible payment plans, or extended tax-filing deadlines in 2020 (OECD, 2020). In addition to short-term financial relief, 
prior to the pandemic, many OECD countries had revised their PITs as instruments to provide supports for the socially and economically disadvantaged (OECD, 2016, 2017, 2018, 2019a).

In addition to its direct impact on family consumption, income tax changes could affect the economy at the macro level. Both the marginal and effective rates of PIT distort the returns of production factors such as labor and capital. As a result, the tax system could influence the labor supply and investment and consequently the allocation of resources across industries and regions (Hines Jr. \& Summers, 2009; Tanzi, 2002). Governments thus have to make difficult decisions to balance multiple policy objectives, including the tradeoff between economic efficiency and interpersonal equity.

Similar to the recent trend among many OECD countries, Taiwan has implemented a series of income tax reforms in recent years. In addition to adjustments on the scope of taxable income and modifications to the tax brackets in attempts to lower the tax burden for specific subpopulations, legislators have pushed for the expansion of income tax deductions to encourage the consumption of certain goods. The goals stated in the proposed or enacted reforms are often ambitious. Still, it is challenging to verify that such goals have been met due to a lack of data, the complexity of income tax codes, and frequent changes in regulation. Our understanding of the impacts of these reforms is thus limited despite its importance.

To shed light on the effect of a recent income tax reform on families, we utilize Taiwan's tax-filing data between 2016 and 2018. We confine our attention to the equity aspect of personal exemptions and deductions. Income inequality is re-emerging as the focal issue in the economic literature. Recent studies have highlighted the deterioration of equality across the world, and Taiwan is no exception to the trend (Bird \& Zolt, 2005; Lee, 2008; Lien et al., 2021; Moriguchi \& Saez, 2008; Piketty \& Saez, 2003; Wu \& Chen, 2018). Income taxes have been identified as potential causes and possible solutions to the increasing interpersonal inequality (Mirrlees \& Adam, 2011; Pechman, 1990; Pfähler, 1990). The administrative data provided by Taiwan's Ministry of Finance can thus give us a rare opportunity to examine similar reforms' distributional implications for families.

In this study, we first calculate and compare the income distributions before and after taxes to provide a basis for discussing the distributional effects of Taiwan's PIT. We then focus on the tax benefits from deductions and exemptions for families across the income spectrum. The tax benefits from income tax are divided into four main categories: exemptions, standard and itemized deductions, special deductions, and adjustments of basic living expenses (BLE). By plotting their concentration curves and calculating the ratio of tax benefits to household income, we illustrate how the adjustments of taxable incomes affect households in different financial conditions. For each of the itemized and special deductions, we also compute two measures: (1) the usage rate, i.e., share of households in each income decile that had claimed the deduction, and (2) the percentage of tax benefits that went to families in each income decile. This dual-parameter metric can help us evaluate the progressivity of the tax benefit for each deduction. Lastly, we construct four representative households and compare how their tax payments change after the reform. The analysis will help illustrate the types of families likely to benefit the most from the expansion of exemptions and deductions.

The remainder of the paper is organized as follows: the next section briefly reviews the discussion of PIT exemptions and deductions in the economic literature. It will be followed by a brief outline of Taiwan's PIT system and its recent reforms. The next sections explain the administrative tax return data, the measures of equality, and our empirical strategy for the study. In the final sections, we present the main results and conclude with a discussion of their policy implications.

\section{Literature on Personal Income Tax Deductions}

The design of income taxation often incorporates various forms of exemptions and deductions, which affect the amount of taxable income to be used as the base to calculate the tax payment owed by an individual or household. Exemptions partially or fully exclude certain sources of earnings from taxable income, while a deduction subtracts some amount from a taxable income or a tax payment to lower one's tax liability.

Kahn (1960) reviewed the development of personal deductions in the United States and summarized their justification into two categories: to encourage particular economic behaviors (such as charitable giving) and to promote equity by lowering taxable income to reflect unavoidable or emergency expenditures (such as medical expenses). For deductions in the first category, their effectiveness as a tool to incentivize certain economic behaviors remains an active and controversial research topic. In traditional economic theory, taxes should be levied on goods or activities in order to address the issue of externality (Pigou, 1920). The ideal amount of tax ought to help the consumer internalize the social benefits or costs of a good that would not be reflected in the market price otherwise, so the quantity demanded after tax can be socially efficient.

The other type of deduction focuses on the equity aspect of income taxation. Since an income tax is a direct tax, exemptions and deductions can incorporate a wide range of personal and household characteristics, including family 
composition, life stages, and personal conditions. In theory, this design should ensure that the final tax payment reflects a taxpayer's ability to pay, which is one of the most basic tenets of optimal taxation. For example, in the United States, the federal income tax allows individuals to deduct medical expenses and mortgage interest payments as itemized deductions to lower their taxable incomes (Department of the Treasury, 2010).

Recent reforms among many OECD countries have adjusted the scope of taxable income in attempts to alleviate financial difficulties faced by the general population or targeted groups while pushing for the expansion of income tax deductions to encourage the consumption of certain goods (OECD, 2016, 2017, 2018, 2019a). In these reforms, oftentimes, policymakers use both efficiency and equity arguments to justify changing exemptions and deductions in the PIT. However, tensions often exist among the multiple policy objectives embedded in the design of income taxation. Frequent regulation changes have made it even more challenging to assess its effectiveness.

The academic literature on the topic is often discussed in the context of tax expenditure, which refers to revenue losses as a result of changes or special provisions of tax laws. In PIT, tax expenditures are realized via the enactments of exemptions, deductions, or tax credits, all of which lower the tax liability for tax-filing households. Since exemptions and deductions are often treated as tax cuts instead of spending programs, researchers have noted their increasing popularity and growth in size in many countries. ${ }^{1}$ Past studies have extensively discussed the economic implications of specific provisions in PIT such as charitable contributions and mortgage interest deductions (e.g., Bourassa \& Yin, 2008; Feldstein \& Clotfelter, 1976; Jensen, 1954; King, 1983; Sommer \& Sullivan, 2018; Taussig, 1967). Recent family economics researchers have also shown interest in specific tax policies aimed at improving the welfare of families in need. For instance, González-Chapela and Ortega-Lapiedra (2021) studied whether Spain's Reduction for Geographic Mobility income tax incentive actually fulfilled its policy objective by promoting internal mobility of the unemployed. Despite spending millions of euros on this tax expenditure measure, the reform's effectiveness was assessed to be minor at best.

Partly due to the complexity of income tax codes and the lack of quality data, few studies have examined the overall distributional effects of income tax among families. Burman et al. (2008) utilized the Tax Policy Center tax simulation model to explore the U.S. federal income tax. The simulation model was constructed based on a representative sample of federal individual income tax returns, which was then used

\footnotetext{
${ }^{1}$ See, for example, Branco and Costa (2018), Burman and Phaup (2012)
}

to estimate the distribution of benefits and tax liabilities for baseline and alternative scenarios. They found that, while the distributional effects of deductions vary substantially, the overall net effect of tax expenditure for individual income tax is regressive. Barbetta et al. (2018) used administrative data to analyze the redistributive effects of Italy's PIT and showed that itemized deductions tend to have little notable impact on income redistribution. Despite its importance, our understanding of the topic remains limited, and the few studies in the literature do not offer a consensus on income taxation's redistributive impact.

Thus, this paper can contribute to the literature by providing a detailed examination of the distribution of tax benefits for families as a result of the recent income tax reform. By utilizing three consecutive years of administrative tax return data collected by Taiwan's Ministry of Finance's Fiscal Information Agency (FIA) between 2016 and 2018, we examine the effectiveness of income tax in improving the equality of income distribution. In addition, by calculating the usage rates, the tax-benefit distributions, and the change of tax payments for representative households, this study demonstrates the types of families that are more likely to benefit from the changes in income tax codes.

\section{Personal Income Tax in Taiwan}

Taiwan's PIT system adopted its current comprehensive and consolidated income tax system in 1968 based upon the territorial principle. Tax residents of Taiwan are required to file a consolidated income tax return based on the tax household unit. $^{2}$ As a tax filing family, dependent family members of the taxpayer and their spouse, whether co-residing or not, can file under the same tax return of the taxpayer. The tax year in Taiwan is based on the calendar year, and the deadline for filing an annual income tax return is the 31 st of May of the following year.

In terms of the scale of contribution, PIT has been one of the most reliable sources of revenue and amounted to roughly $20 \%$ of the total tax collection. See Table 1 for the comparison between PIT, total tax revenue, and GDP in Taiwan.

When viewed in an historical context, much has changed in Taiwan's income tax system since its inception in 1956 as a narrowly defined separate income system. In what follows, we present a brief survey of the major changes related to exemptions and deductions. The course of reforms vividly

\footnotetext{
${ }^{2}$ See p.32, Chapter II, Individual Income Tax, Section VI. Tax Returns and Payments, Sub Section C. Consolidated Return, Guide to ROC Taxes, 2019.
} 
Table 1 PIT, total tax revenue, and GDP (in TWD)

\begin{tabular}{|c|c|c|c|c|c|c|c|}
\hline Year & Personal income tax & Growth rate $(\%)$ & Total tax revenue & Growth rate $(\%)$ & PIT shares $(\%)$ & $\begin{array}{l}\text { GDP (thou- } \\
\text { sand dollars) }\end{array}$ & Tax-to-GDP (\%) \\
\hline 2005 & $296,449,973$ & & $1,567,396,363$ & & 18.91 & $12,036,675$ & 13.02 \\
\hline 2006 & $334,330,223$ & 12.78 & $1,600,803,894$ & 2.13 & 20.89 & $12,572,587$ & 12.73 \\
\hline 2007 & $347,526,356$ & 3.95 & $1,733,894,782$ & 8.31 & 20.04 & $13,363,917$ & 12.97 \\
\hline 2008 & $389,743,539$ & 12.15 & $1,760,438,282$ & 1.53 & 22.14 & $13,115,096$ & 13.42 \\
\hline 2009 & $306,804,192$ & -21.28 & $1,530,282,190$ & -13.07 & 20.05 & $12,919,445$ & 11.84 \\
\hline 2010 & $304,686,208$ & -0.69 & $1,622,244,070$ & 6.01 & 18.78 & $14,060,345$ & 11.54 \\
\hline 2011 & $343,004,982$ & 12.58 & $1,764,610,616$ & 8.78 & 19.44 & $14,262,201$ & 12.37 \\
\hline 2012 & $393,065,301$ & 14.59 & $1,796,697,193$ & 1.82 & 21.88 & $14,677,765$ & 12.24 \\
\hline 2013 & $392,174,282$ & -0.23 & $1,834,124,153$ & 2.08 & 21.38 & $15,270,728$ & 12.01 \\
\hline 2014 & $410,852,287$ & 4.76 & $1,976,106,922$ & 7.74 & 20.79 & $16,258,047$ & 12.15 \\
\hline 2015 & $473,946,434$ & 15.36 & $2,134,857,093$ & 8.03 & 22.20 & $17,055,080$ & 12.52 \\
\hline 2016 & $495,971,933$ & 4.65 & $2,224,075,454$ & 4.18 & 22.30 & $17,555,268$ & 12.67 \\
\hline 2017 & $483,099,840$ & -2.60 & $2,251,246,001$ & 1.22 & 21.46 & $17,983,347$ & 12.52 \\
\hline 2018 & $509,134,609$ & 5.39 & $2,386,944,903$ & 6.03 & 21.33 & $18,886,878$ & 12.64 \\
\hline
\end{tabular}

Authors' computation from data provided on Ministry of Finance's Public Finance Statistics Database (http://web02.mof.gov.tw/njswww/webma in.aspx?sys=100\&funid=edefjspf2) and Directorate General of Budget, Accounting and Statistics (DGBAS) National Accounts (https://eng.stat. gov.tw/np.asp?CtNode=1539)

reflects the economic and social developmental path of Taiwan for the past half-century.

The concept of allowing for exemptions and deductions owed its origin to the 1956 PIT prototype. Specifically, donations, insurance premiums, medical and childbirth expenses, and disaster losses were already coded as eligible deductions with various caps in 1956's provisions. In 1963, loss from property transactions was added into the above list of deductions, and the taxpayers were given an option when itemizing deductions to simply take a fixed ten percent (of the total declared income) as a standard deduction. In 1975, the system sought to distinguish between standard, itemized, and special deductions by introducing the special deduction for wage income as a $10 \%$ item. In 1981, the special savings and investment deduction came into being and was capped at NTD 120,000. When housing prices tripled in the late 1980s (Tsai \& Peng, 2011), PIT changes were made in 1988 to allow for an itemized mortgage interest deduction with an NTD 20,000 cap. In 1990, taxpayers and dependents were able to claim a special disability deduction, and the special deduction for wage income was revised into a fixed amount (NTD 12,000) rather than a fixed percentage deduction item. In 1993, the special deduction for college tuition was adopted and capped at NTD 20,000. In 2001, a $50 \%$ additional increase in the personal exemption for lineal ascendants aged 70 and above was written into the tax codes. In 2013, the preferential treatment of exempting the wages of military service members and primary and tertiary teachers was removed. That same year, qualified tax-filing families were able to claim a special deduction for preschool childcare. The unique feature of the childcare deduction was that it was the first means-tested deduction that excluded the top three marginal tax rate filing families. The allowed deduction for wage income was then hiked in 2015 to NTD 128,000 and quickly increased by another $56 \%$ in 2018 to NTD $200,000 .^{3}$ It is noteworthy that the path of reform exhibits two different modes. First, except for the 2013 removal of the exemption on wages of military service members and primary and tertiary teachers, PIT policy has been to expand the scope and the amount of deductions through the years. Second, the introduction of the special preschool care deduction as the first means-tested tax expenditure measure may inspire a reassessment of the equity implications of all other deductions in future policy discussions. ${ }^{4}$

For the purpose of this study, we now turn to the fundamental structure of Taiwan's PIT return in the following formulae, ${ }^{5}$

\footnotetext{
${ }^{3}$ Legislative History of Income Tax Act, https://law.moj.gov.tw/ ENG/LawClass/LawHistory.aspx?pcode $=\mathrm{G} 0340003$ (accessed on Feb. 2, 2021); and ROC Legal Information Database of Legislative Yuan, Revision History on Article 17, Income Tax Act https://glin. ly.gov.tw/web/index.do?isChinese $=$ false (accessed on Feb. 2, 2021).

${ }^{4}$ Indeed in 2018, the Legislative Yuan passed a new special deduction for long-term care (effective at tax year 2019) which followed the exact means-tested rule of the preschool care deduction. See Legislative History of Income Tax Act, Article 17, https://law.moj.gov.tw/ ENG/LawClass/LawSearchContent.aspx ?pcode $=$ G0340003\&norge $=$ 17 (accessed on May 9, 2021).

5 A assessment of tax payable by matching the total net taxable income with the highest marginal tax rate $(0 \%, 5 \%, 12 \%, 30 \%$, and $40 \%$ ) will generate excessive tax liability. "Progressive Difference" is simply the term to be subtracted from that formula to render a correct amount of tax payable.
} 
Table 2 Exemption for tax year 2016-2018 (in TWD)

\begin{tabular}{|c|c|c|}
\hline \multirow[t]{2}{*}{ Tax year } & \multicolumn{2}{|l|}{ Exemption } \\
\hline & $\begin{array}{l}\text { Each taxpayer, spouse, and } \\
\text { dependents }\end{array}$ & $\begin{array}{l}\text { Each lineal ascend- } \\
\text { ant age } 70 \text { and } \\
\text { above }\end{array}$ \\
\hline 2016 & 85,000 & 127,500 \\
\hline 2017 & 88,000 & 132,000 \\
\hline 2018 & 88,000 & 132,000 \\
\hline
\end{tabular}

to the tax-filing income, Taiwan's $71 \%$ in 2018 is much greater than Hong Kong's 41\% (2017-2018), Singapore's $16 \%$ (2018), Germany's 16\% (2016) and the UK's 35\% (2016-2017). ${ }^{7}$ Researchers have now shown renewed interest in studying how these tax expenditure measures impact equity.

While itemized deductions are traditionally thought to favor wealthier families in anecdotal narratives, mixed findings occur on this line of inquiry when different PIT systems are presented in different policy settings. Barbetta et al. (2018) believe that most of the itemized expenditures

Gross Income-Personal Exemptions - Deductions - Adjustment of Basic

Living Expenses (applicable in 2017 and 2018)=Net Taxable Income

Net Taxable Income*(marginal) Rate-Progressive Difference=Tax Payable

It is clear from the above expressions that exemptions, deductions, and progressive marginal tax rates are the key elements in shaping the vertical equity or lack thereof. ${ }^{6}$ When assessing the personal exemptions, a family multiplies the total number of persons filed in the tax return by a flat dollar amount adjusted for inflation. An extra $50 \%$ of the personal exemption is granted to lineal ascendants aged 70 or over. Other than the automatic CPI indexation adjustment, there were no policy changes observed during the recent years for personal exemptions. We tabulate the rules and amount granted to an individual in Table 2.

A more interesting tax planning problem arises when tax-filing families choose between claiming the standard deduction or claming itemized deductions. Suppose a family forgoes claiming the standard deduction and elects to itemize. In that case, the taxpayer will subtract from Gross Income (GI) the dollar amount of certain expenses incurred by the taxpayer, subject to certain capping limitations. Thus, a taxpayer will generally opt to claim the standard deduction if it is higher than the taxpayer's total itemized deductions.

To facilitate an international comparative perspective, we compile Table 3 to demonstrate the tax expenditure tools (deductions and tax credits) employed by neighboring Asian economies (China, Hong Kong, Singapore, South Korea, and Japan) and other major countries (the United States, Germany, Italy, Spain, and the UK). It shows that Taiwan has resorted to much broader items of deductions than all the surveyed countries. Furthermore, with regard to the estimated ratio of total exemptions and deductions

\footnotetext{
6 There are currently an "investment tax credit" and a residential property "repurchase tax credit" associated with Taiwan's PIT. We do not address their distributional effects in this paper mainly because these tax credits exhibit time-lagging natures.
}

in Italian PIT do not show any sizable impact on redistribution. Cauble (2017) argues that Trump's U.S. tax reform may see itemized deductions disproportionately benefitting higher-income individuals even with the increase in the standard deduction and the elimination or reduction in various itemized deductions. Zhan et al. (2019) predict an equity-worsening (in terms of the Gini coefficient) and revenue losing scenario in a simulation study featuring China's recent PIT deduction-expanding reform. Hence, a study on Taiwan's PIT tax reform with detailed administrative data renders broad ramifications.

More institutional features are presented in Table 4, which lists the rules and caps regarding itemized deductions in Taiwan's PIT.

One rather unique feature of Taiwan's PIT is to allow tax filing families to claim additional special deductions that work just like personal exemptions irrespective of whether the tax filing family has selected itemized deductions or the standard deduction. These include, ${ }^{8}$

(1) Losses from property transactions;

(2) Special deduction for wage income;

(3) Special deduction for savings and investment (i.e., interest income);

(4) Special deduction for the (physically or mentally) disabled;

\footnotetext{
7 Tax years are in the parentheses. Calculations are performed on those surveyed countries that report official statistics of those components of the said ratio. Estimates are available from the authors upon request.

${ }^{8}$ These special deductions come into existence from the prodding of many different interest groups, as can be seen in their widely divergent definitions and scopes.
} 


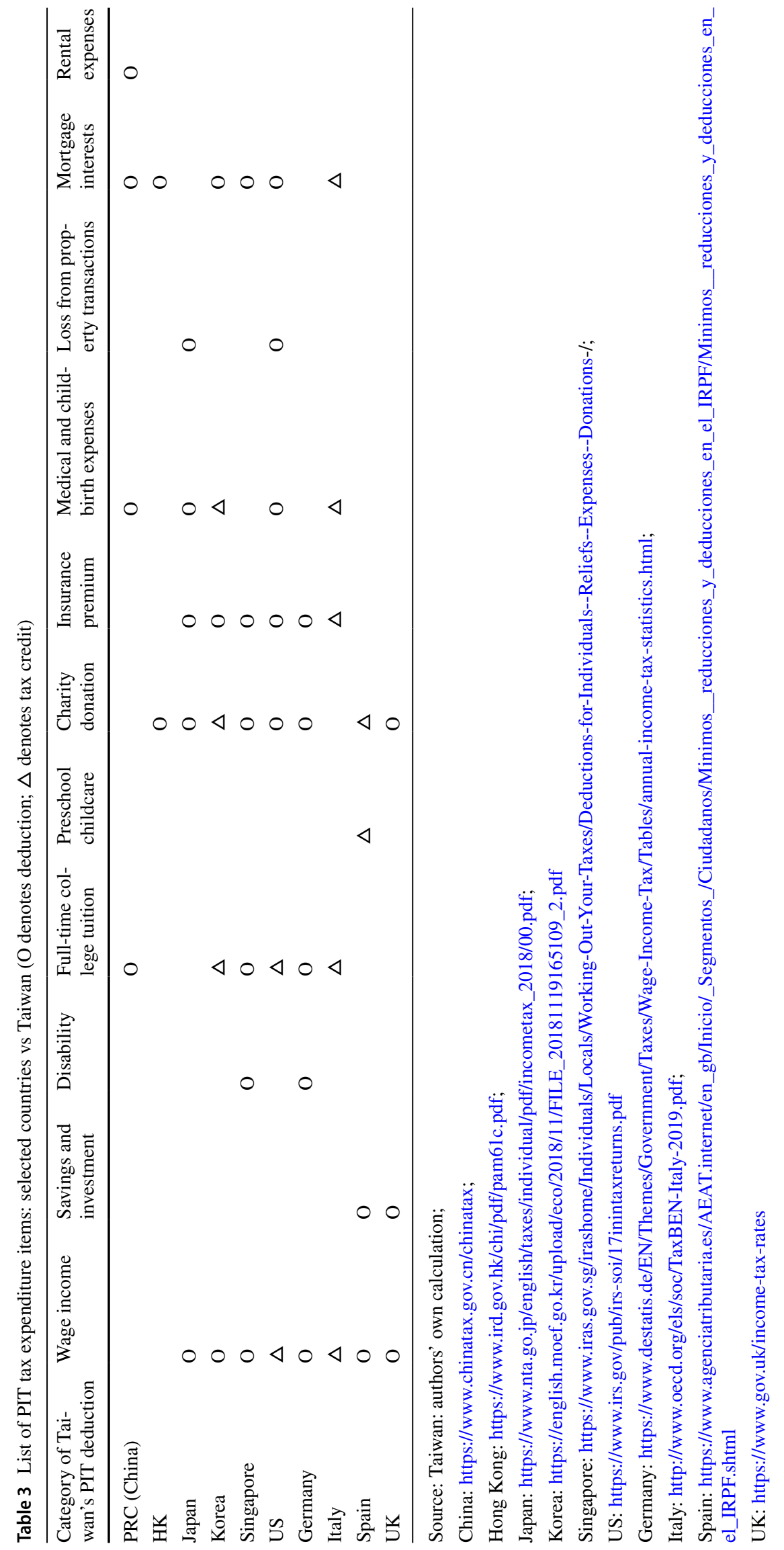


Table 4 Itemized Deductions (in TWD)

\begin{tabular}{|c|c|}
\hline Deductible items & Rate and amount of allowance \\
\hline $\begin{array}{l}\text { Donations made to the government or to } \\
\text { boost military morale or for the purpose } \\
\text { of national defense }\end{array}$ & Fully deductible \\
\hline $\begin{array}{l}\text { Donations to private schools through the } \\
\text { foundation referred to in the Private } \\
\text { School Law }\end{array}$ & Not exceeding $50 \%$ of the gross consolidated income \\
\hline Insurance Premiums & $\begin{array}{l}\text { NT } \$ 24,000 \text { per person for insurance premiums paid by the taxpayer, his or her spouse or lineal } \\
\text { dependent(s) on life insurance, labor insurance, national pension insurance, and insurance for } \\
\text { military personnel, public servants, or teachers } \\
\text { National health insurance premium is fully deductible }\end{array}$ \\
\hline Qualified Medical and Childbirth expenses & Fully deductible \\
\hline Disaster losses & Fully deductible \\
\hline Mortgage interest & $\begin{array}{l}\text { Mutually exclusive; only one deduction is } \\
\text { applicable }\end{array}$ \\
\hline Rental expenses & $\begin{array}{l}\text { Not exceeding } \\
\text { NT } \$ 120,000 \\
\text { per filing family }\end{array}$ \\
\hline
\end{tabular}

The itemized deduction on political donation is not discussed here since the amount of allowance is separately regulated under the Political Donation Act instead of the Income Tax Act

Table 5 Standard and special deductions for tax year 2016-2018

\begin{tabular}{|c|c|c|c|c|c|c|c|}
\hline \multirow[t]{2}{*}{ Tax year } & \multicolumn{2}{|c|}{ Standard deductions } & \multicolumn{5}{|c|}{ Special deductions } \\
\hline & Single & Married couple & $\begin{array}{l}\text { Wage income } \\
\text { (per earner) }\end{array}$ & $\begin{array}{l}\text { Saving and invest- } \\
\text { ment (per filing } \\
\text { unit) }\end{array}$ & Full-time college tuition & Preschool care & Disability \\
\hline 2016 & 90,000 & 180,000 & 128,000 & 270,000 & 25,000 per enrolment & 25,000 per child & 28,000 per person \\
\hline 2017 & 90,000 & 180,000 & 128,000 & 270,000 & 25,000 per enrolment & 25,000 per child & 28,000 per person \\
\hline 2018 & 120,000 & 240,000 & 200,000 & 270,000 & 25,000 per enrolment & 120,000 per child & 200,000 per person \\
\hline
\end{tabular}

(5) Special deduction for certified full-time college tuition; and

(6) Special deduction for preschool children (under or equal to five years of age).

Table 5 tabulates recent changes in standard and special deductions for the tax years 2016 to 2018 . Note that the increases observed in various deductions from 2017 to 2018 were not due to the CPI indexing mechanism, but rather they resulted from the Ministry's proactive amendments to the Income Tax Act. ${ }^{9}$

\section{The Basic Living Expenses experiment}

The Taxpayer Rights Protection Act was borne out of many years of legal battles at the Legislative Yuan (the unicameral legislature of Taiwan), starting as early as 2006, and then at the constitutional court. It was finally enacted in 2016 and became effective for the 2017 tax year "for the purposes of implementing the protection of the existence right, work right, property right, and other relevant basic rights in the Constitution of the Republic of China [Taiwan], insuring rights of taxpayers, achieving tax equity, and carrying through the due process of law." 10

At the core of the Taxpayer Rights Protection Act is the newly added special deduction of basic living expenses (BLE) from a family's taxable income. The BLE deduction is

\footnotetext{
${ }^{10}$ Article 1, Taxpayer Rights Protection Act, https://law.moj.gov.tw/ ENG/LawClass/LawAll.aspx?pcode $=$ G0340142 (accessed on August 09, 2020).
}

9 This reform was named "Optimal Adjustment of Income Tax System". Please refer to https://www.dot.gov.tw/Eng/singlehtml/en_177? cntId=dot_201909160001_177 (accessed on November 09, 2020). 
Table 6 Rules of claiming basic living expenses for tax year 2017-2018

\begin{tabular}{|c|c|c|}
\hline \multicolumn{3}{|l|}{ Adjustment of basic living expenses } \\
\hline For tax year 2017 & \multicolumn{2}{|l|}{ For tax year 2018} \\
\hline $\begin{array}{l}\text { Basic living expenses }=\mathrm{NT} \$ 166,000 \text { multiplied by the number of tax- } \\
\text { payers, their spouses, and dependents }\end{array}$ & \multicolumn{2}{|c|}{$\begin{array}{l}\text { Basic living expenses }=\mathrm{NTT} \$ 171,000 \text { multiplied by the number of } \\
\text { taxpayers, their spouses, and dependents }\end{array}$} \\
\hline $\begin{array}{l}\text { The amount of total basic living expenses in excess of the total exemp- } \\
\text { tion, general deductions (either standard or itemized deductions), } \\
\text { special deductions for wage income, for savings and investment, for } \\
\text { the disabled, for college education tuition, and for preschool children, } \\
\text { may be deducted from the gross consolidated income of the taxpayer }\end{array}$ & \multicolumn{2}{|c|}{$\begin{array}{l}\text { The amount of total basic living expenses in excess of the total exemp- } \\
\text { tion, general deductions (either standard or itemized deductions), } \\
\text { special deductions for savings and investment, for the disabled, } \\
\text { for college education tuition, and for preschool children, may be } \\
\text { deducted from the gross consolidated income of the taxpayer }\end{array}$} \\
\hline \multicolumn{3}{|l|}{ Items related to computing Adjustments of BLE (in TWD) } \\
\hline Items & Tax Year 2017 & Tax Year 2018 \\
\hline Exemption (per person) & 88,000 & 88,000 \\
\hline Standard deduction (single/couple) & $90,000 / 180,000$ & $120,000 / 240,000$ \\
\hline Special deduction for savings and investment & Excluded & Newly included \\
\hline Special deduction for the disabled (per person) & Excluded & Newly included \\
\hline Special Deduction for College Tuition & Excluded & Newly included \\
\hline Special deduction for preschool care & Excluded & Newly included \\
\hline Special deduction for wage income & 128,000 (per person) & Excluded \\
\hline Special deduction for loss from property transactions & Excluded & Excluded \\
\hline
\end{tabular}

biannually assessed by the Department of Budget, Accounting, and Statistics by tapping the " $60 \%$ of the median rate of the expenditure per person in the past year." ${ }^{11}$ What complicates the matter of computing tax liability further is that the BLE deduction only grants a symbolic individual allowance but not a flat-dollar amount. The final verdict depends on a floating adjustment criterion to BLE, which we demonstrate in Table 6 and Eqs. 3 and 4.

Alternatively, we express the adjustment of BLE with the following formulae,

BLE(2017)*number of household members-Personal Exemption

- Deductions(standard or itemized)

- (special deduction for wage)

$=$ Adjustment of BLE (2017)

BLE(2018)*number of household members - Personal Exemption

$$
\begin{aligned}
& \text { - Deductions(standard or itemized) } \\
& \text { - (special deduction for savings and investment }) \\
& \text { - (special deduction for the disabled) } \\
& \text { - (special deduction for college tutition) } \\
& \text { - (special deduction for preschool care) } \\
& \text { = Adjustment of BLE (2018) }
\end{aligned}
$$

The question about how tax and its benefits shape family incomes is drawing not only academic interest but also the attention of many countries' policymakers. As the OECD's recent research reveals, over the past 30 years, middle-income households have experienced dismal income growth or even stagnation in some countries. ${ }^{12}$ There are perceptions that the current socio-economic system is so unsympathetic to wage earners, mortgage payers, aging seniors, and families with children, and they easily fuel the policymakers' enthusiasm to broaden the scope of tax expenditure in the abovementioned categories.

In an affort to rescue those in the "squeezed middle", Taiwan's Ministry of Finance announced that, "in 2018, the standard deduction, the special deduction for wage income, and the special deduction for the disabled would be significantly increased, with increases of from 33 to $56 \%$ to relieve the tax burden on middle- and low-income earners and wage income earners and improve the distribution of income."13 However, the tax authority's reform to broaden the scope of deductions sharpens a double-edged sword because it

\footnotetext{
11 Article 4, Taxpayer Rights Protection Act, https://law.moj.gov.tw/ ENG/LawClass/LawAll.aspx?pcode $=\mathrm{G} 0340142$ (accessed on August 09, 2020).
}

\footnotetext{
12 OECD (2019b), Under Pressure: The Squeezed Middle Class, Paris. https://www.oecd.org/social/under-pressure-the-squeezed-middle-class-689afed1-en.htm

${ }^{13}$ Fair Taxation, Major Measures Achieved by the Ministry of Finance, https://www.mof.gov.tw/Eng/multiplehtml/7015 (accessed on August 09, 2020).
} 
Table 7 Descriptive statistics of the administrative tax return data (in TWD)

\begin{tabular}{lllrrr}
\hline Obs & Mean & Medium & Total gross income & Std & \multicolumn{1}{c}{ Range } \\
\hline $6,224,134$ & 933,707 & 621,898 & $5,811,520,263,601$ & $5,159,491$ & $10,315,644,687$ \\
$6,304,444$ & 943,733 & 627,449 & $5,949,687,932,396$ & $4,310,639$ & $7,783,920,126$ \\
$6,271,521$ & $1,011,172$ & 650,740 & $6,341,596,942,310$ & $6,592,439$ & $6,815,622,386$ \\
\hline
\end{tabular}

will certainly erode the already small tax base ${ }^{14}$ Note that Taiwan's tax-to-GDP ratio dwindled from $17.5 \%$ in 1995 to $13.4 \%$ in 2008. In 2016, statistics from the Ministry of Finance revealed that 6.22 million returns amounted to a GI of NTD 5.8 trillion but $62 \%$ of that income was free of tax liability after accounting for qualified exemptions and deductions. Consequently, the continued erosion of the PIT base resulted in a meager 5.57\% effective tax rate in 2016. Taiwan's Ministry of Finance acknowledges the urgency in reforming the tax codes related to the schemes of exemptions and deductions. ${ }^{15}$

It is then imperative to investigate the recently enacted PIT tax reform and its broad ramifications. The new tax legislation certainly has changed the landscape for families' tax liabilities. In order to disentangle the complex interaction among exemptions, deductions, and BLE across different compositions of families, we turn our attention to the administrative tax return data.

\section{Data and Methods}

\section{The Administrative Tax Return Data}

The Fiscal Information Agency (FIA) is the data czar of taxation statistics in Taiwan. ${ }^{16}$ It was formerly known as the Financial and Taxation Data Processing and Examination Center and was founded jointly by the Taxation Reform Commission and the Ministry of Finance in 1968 with the aim to improve the overall taxation administration. It was later wholly integrated under the Ministry of Finance and was renamed the FIA in 2013. All tax filing data are collected and compiled for auditing and, in recent years, for research use. Chu et al. (2015) were the first researchers to utilize the FIA's administrative income tax return data to develop top income share statistics in Taiwan. Now the research insights have been broadened to understand

\footnotetext{
${ }^{14}$ It has been speculated that a sizable underground economy and the lack of tax treaties signed between Taiwan and other tax regions are both contributing factors to this way-too-small income tax base. Finance Minister Su Jiang-Rong estimated "the black economy is equivalent to between 25 and 30\% of GDP." See Ellis, E. (2019). Taiwan's finance system: NOT-SO-CRAZY, rich and regulated, https:// www.asiamoney.com/article/b1g114y22xsw8h/taiwans-finance-system-not-so-crazy-rich-and-regulated (accessed on November 09, 2021).

15 Press Release (in Chinese), Ministry of Finance, September 20, 2018 https://www.mof.gov.tw/singlehtml/384fb3077bb349ea973e $7 \mathrm{fc} 6 \mathrm{f} 13 \mathrm{~b} 6974$ ? $\mathrm{cntId}=\operatorname{dot} 80930$ (accessed on August 09, 2020).

16 https://www.fia.gov.tw/eng/singlehtml/85 (accessed on August 09, 2020).
}

intergenerational earnings mobility (Chu \& Lin, 2020) and wealth distribution (Lien et al., 2021).

As shown in Table 7, similar to the income distribution of most countries, Taiwan's total gross income (TGI) is highly skewed to the right, which is indicated by the considerable difference between the median and average income. While the spread of the distribution narrowed over time, which is indicated by the narrowing of the TGI's range, at the same time, its standard deviations were rising. While the difference in GI between the absolute richest and the most impoverished household was decreasing, its distribution also became more dispersed. The implication for income equality is thus unclear based on these two descriptive measures.

Table 8 shows that recent reforms had drastically reduced the average and effective tax rates, both of which were at their lowest levels in the past decade. The average tax rate was lowered to $11.5 \%$ in 2018 , and the effective tax rate went from about $5.6 \%$ in $2016 / 17$ to $3.7 \%$ in 2018 . The substantial cut in the effective tax rate ( $2 \%$ points) was partly due to the sizable reduction in the tax base. In 2018, more than half $(51.13 \%)$ of the households had their GIs completely waived from taxation due to the new tax codes, particularly due to the adjustment of BLE.

Table 8 Average and effective tax rates for tax year 2016-18

\begin{tabular}{lllll}
\hline Tax year & $\begin{array}{l}\text { Average } \\
\text { tax rate } \\
(\%)\end{array}$ & $\begin{array}{l}\text { Effective } \\
\text { tax rate } \\
(\%)\end{array}$ & $\begin{array}{l}\text { Total tax pay- } \\
\text { able (million } \\
\text { NTD) }\end{array}$ & $\begin{array}{l}\text { Erosion of the } \\
\text { tax base }(\%)\end{array}$ \\
\hline 2005 & 13.69 & 6.63 & 278,621 & 26.51 \\
2006 & 13.88 & 6.44 & 276,748 & 28.92 \\
2007 & 14.04 & 6.69 & 307,663 & 27.60 \\
2008 & 14.86 & 6.60 & 314,740 & 35.43 \\
2009 & 13.64 & 5.38 & 228,675 & 41.53 \\
2010 & 13.03 & 5.67 & 260,829 & 38.29 \\
2011 & 13.37 & 6.11 & 304,995 & 35.16 \\
2012 & 12.62 & 5.79 & 311,840 & 32.44 \\
2013 & 12.29 & 5.38 & 284,500 & 35.55 \\
2014 & 14.06 & 6.66 & 384,879 & 33.20 \\
2015 & 12.84 & 5.59 & 320,052 & 36.82 \\
2016 & 12.69 & 5.57 & 323,987 & 35.87 \\
2017 & 12.70 & 5.56 & 330,921 & 36.29 \\
2018 & 11.46 & 3.66 & 232,083 & 51.13 \\
\hline
\end{tabular}

Erosion of the tax base refers to the percentage of tax-filing households with zero taxable income after exemptions, deductions, and adjustments of basic living expenses 


\section{Empirical Strategy}

To capture the overall impact of PIT on income distribution, we first measure the change in Gini coefficients due to income tax and compare the Lorenz curves of the GI and after-tax income distributions. We then examine the equality of distribution for four main categories of income tax benefits: personal exemptions, standard deductions, special deductions, and adjustments of BLE. By plotting their concentration curves and calculating the ratio of tax benefits to household income, we illustrate how these adjustments of taxable incomes affect households in different financial conditions. We also calculate the ratios of tax benefit to income for various family compositions to compare the impacts of income tax codes across different types of family compositions. Lastly, for each itemized and special deduction, we compute two measures: (1) the share of households in each income decile that had claimed the deduction and (2) the share of tax benefits that went to families in each income decile. These results can help us evaluate the progressivity of each deduction's tax benefits across the economic spectrum.

\section{Measures of Income Inequality}

In this section, we define the key variables used in the analysis, and we present our findings in the following section. To evaluate the effect of PIT on equality, we first utilize the Lorenz curves and their variants. The standard Lorenz curve captures the graphical deviations from an equal income distribution by plotting the cumulative share of the poorest of households against the cumulative share of their income (Lorenz, 1905). Unlike other inequality measures, the Lorenz curve assesses the degree of inequality in a scale-free manner and it is based on the complete distribution. It has been widely used in the literature to evaluate the equality of distribution for income, wealth, and other socio-economic variables (see, for example, Aronson \& Lambert, 1994; Gastwirth 1972; Jann 2016; Lambert 2001; Yitzhaki \& Schechtman, 2013).

In the context of this paper, the Lorenz curve is defined to measure the cumulative distribution of tax-filing households' annual income. Let $X$ denote the GI of taxpayers, and let $J$ denote the total number of income quantiles that are measured in the administrative data. Suppose $X_{i}$ represents the GI of taxpayers in the $i$ th quantile and $X_{i}$ is arranged in ascending order; in other words, $X_{1}$ is based on the poorest households and $X_{J}$ the richest ones. The Lorenz curve for our grouped tax-return data can be then calculated as:
Table 9 Redistributive effects of personal income tax

\begin{tabular}{lllll}
\hline Year & $\begin{array}{l}\text { Gini Coef. } \\
\text { DGBAS }\end{array}$ & $\begin{array}{l}\text { Gini Coef. } \\
\text { gross income }\end{array}$ & $\begin{array}{l}\text { Gini Coef. } \\
\text { after-tax } \\
\text { income }\end{array}$ & $\begin{array}{l}\text { Differences } \\
\text { due to PIT (\%) }\end{array}$ \\
\hline 1999 & 0.325 & 0.421 & 0.403 & -4.34 \\
2000 & 0.326 & 0.429 & 0.408 & -5.01 \\
2001 & 0.350 & 0.433 & 0.413 & -4.61 \\
2002 & 0.345 & 0.432 & 0.415 & -4.05 \\
2003 & 0.343 & 0.440 & 0.422 & -3.96 \\
2004 & 0.338 & 0.440 & 0.418 & -4.97 \\
2005 & 0.340 & 0.449 & 0.426 & -5.20 \\
2006 & 0.339 & 0.451 & 0.428 & -5.08 \\
2007 & 0.340 & 0.459 & 0.436 & -5.12 \\
2008 & 0.341 & 0.462 & 0.438 & -5.33 \\
2009 & 0.345 & 0.452 & 0.432 & -4.49 \\
2010 & 0.342 & 0.468 & 0.447 & -4.56 \\
2011 & 0.342 & 0.472 & 0.449 & -4.80 \\
2012 & 0.338 & 0.462 & 0.441 & -4.58 \\
2013 & 0.336 & 0.464 & 0.444 & -4.23 \\
2014 & 0.336 & 0.481 & 0.457 & -5.07 \\
2015 & 0.338 & 0.467 & 0.446 & -4.43 \\
2016 & 0.336 & 0.466 & 0.445 & -4.41 \\
2017 & 0.337 & 0.467 & 0.446 & -4.39 \\
2018 & 0.338 & 0.454 & 0.439 & -3.31 \\
Average & 0.339 & 0.454 & 0.433 & -4.60 \\
\hline & & & & \\
\hline
\end{tabular}

DGBAS Gini Coefficients (which include transfer from government) are retrieved from the Report on the Survey of Family Income and Expenditure (2019) conducted by Directorate General of Budget, Accounting and Statistics at https://win.dgbas.gov.tw/fies/e11.asp? year $=108$

$L_{X}(i)=\frac{\sum_{j=1}^{i} X_{j}}{\sum_{j=1}^{J} X_{j}}, i \in(1, J)$

The Lorenz curve measures the share of outcome variable $X$ in proportion to the share of the population ranked by the same variable. It can be extended to a bivariate variant that plots the cumulative share of outcome variable $Y$ against the cumulative share of the population ranked by income $X$. This variant of the Lorenz curve is often referred to as a concentration curve since it is used to illustrate the concentration of certain outcomes in a population ranked by socio-economic status (O'donnell et al. 2007).

In our analysis, we divided the taxpayers into ten income quantiles. Each observation on the Lorenz curve thus represents the share of cumulative income from the bottom $i$ deciles of taxpayers. If the incomes are distributed equally, the proportion of total income from the bottom $i$ deciles of taxpayers would be exactly $i / J$. For instance, the cumulative income from the poorest $50 \%$ of taxpayers $(i=5)$ should be 0.5 under equal distribution. The equality gap $(E)$ between the actual 


\section{Inequality among tax-filing households}

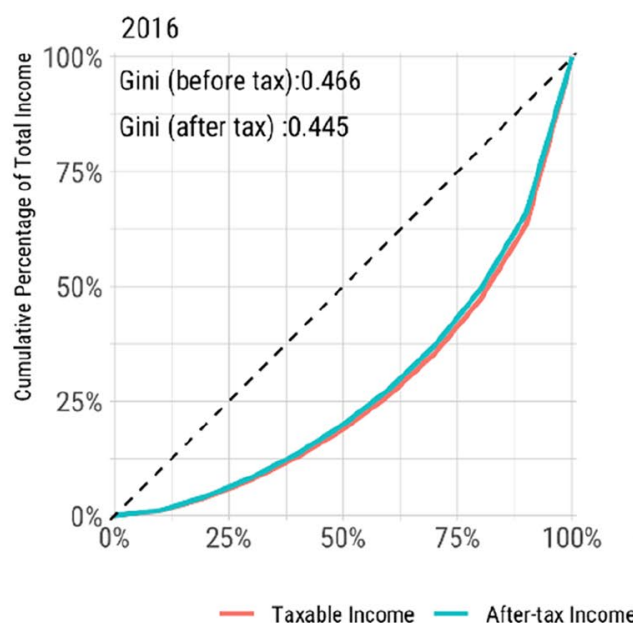

Fig. 1 Lorenz curves for gross income and after-tax income, 2016-2018

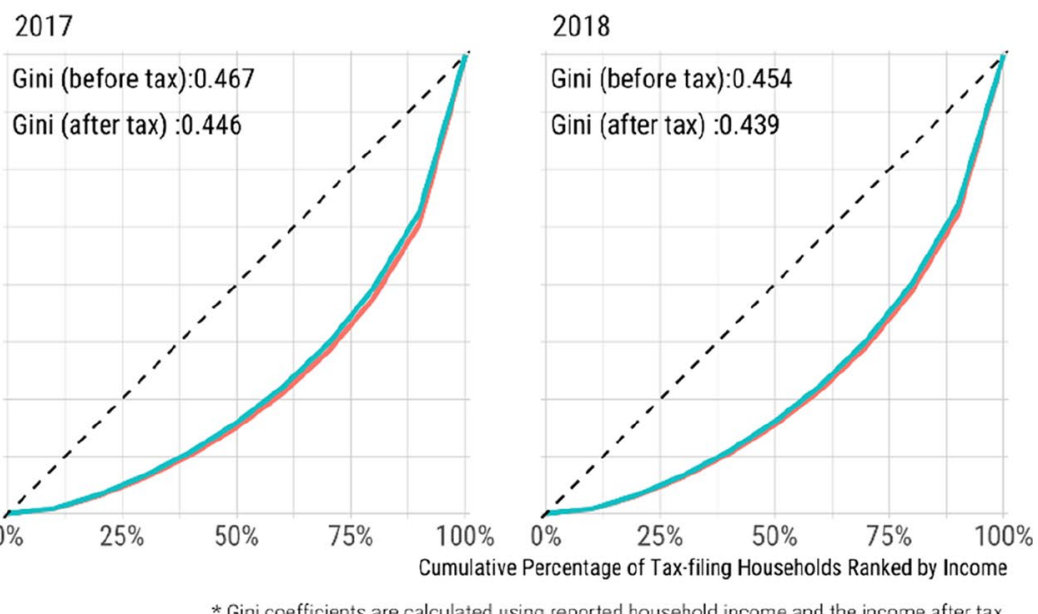

* Gini coefficients are calculated using reported household income and the income after tax. distribution and the hypothetical equal distribution for the $i$ th income decile can thus be defined as:

$E_{X}(i)=i / J-L_{X}(i)$

The Gini coefficient, which summarizes the overall inequality as a single index, can then be expressed as the ratio of the sum of equality gaps to the sum (total area) of the Lorenz curve components:

$G=\frac{\sum_{i} E_{X}(i)}{\sum_{i} L_{X}(i)}$

In addition to the distribution of benefits, we will measure the equality of income tax deductions by the ratio of tax benefits to household GI $\left(R_{i}\right)$, which is defined as the following:

$R_{i, y}=\frac{B_{i, y}}{X_{i, y}}$

where $B_{i, y}$ denotes the total tax benefits, which refers to the nominal value of the income deductions and exemptions claimed by the households in the $i$ th income decile in year $y$, and $X_{i, y}$ is the total reported GI for taxpayers in the same decile during the given year.

\section{Results}

We first examine the overall redistributive effect of PIT, calculating the Gini coefficients for gross consolidated income and the after-tax income. Gini coefficients derived from the official bi-annual Survey of Family Income and Expenditure and our coefficients and their differences derived from the tax data are then presented in Table 9. Gini coefficients' differential between the government's survey and our calibration resonates what recent inequality research such as Burkhauser et al. (2012) has pointed out: a Gini coefficient may not capture the growth at the top income households (it is noticeable that the Gini coefficient based on the DBGAS survey grew at most $7.7 \%$ while our tax return Gini coefficient grew at most $14.25 \%$ during this 20 -year period). ${ }^{17}$

We also observe that PIT had contributed to the improvement of income distribution after tax. Between 1999 and 2018, the Gini coefficients for the income distribution among tax-filing households were reduced by $4.6 \%$ on average.

The redistributive effect of PIT, however, appears to be declining in recent years. In Fig. 1, we plot the cumulative proportion of income against the cumulative proportion of the population ranked by their income. The 45-degree line identifies the equal distribution of income, and the curves closer to the equality line represent a more equal distribution. While the income distribution after tax was more equal than the GI, the improvements were only marginal between 2016 and 2018, despite the reform.

To compare the distribution of tax benefits for various types of deductions, we plot the cumulative proportion of benefits against the population ranked by their GI in Fig. 2 . A concentration curve closer to the 45-degree equality line indicates a more equal distribution of benefits, and if the curve is above the equality line, the benefits are distributed

\footnotetext{
17 Burkhauser et al. (2012) find that from the early 1990s through the 2000s, IRS tax return data literature has observed much larger increases in income inequality than what the March Current Population Survey (CPS) public use data's coefficients indicated.
} 


\section{Distribution of Tax Benefits}

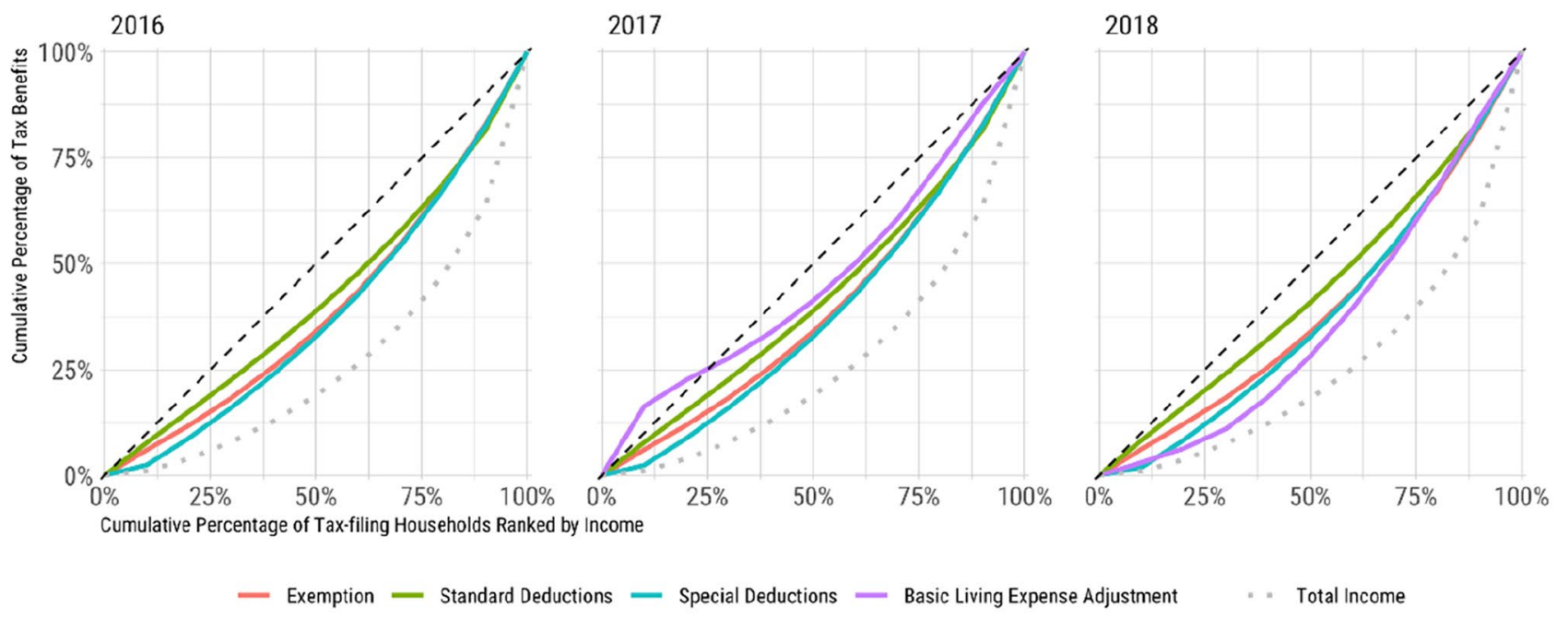

Fig. 2 Concentration curves of tax deductions, 2016-2018. Grouped data tables generated during the study to produce the charts are available from the authors upon request

progressively. In general, the distribution of benefits from income tax deductions favors higher-income families. Among the four categories of deductions, only the adjustments for BLE were progressive in 2017. Since the BLE adjustments are designed to ensure that the total value of the deductions is higher than the statutory threshold, its progressivity depends on the other deductions. Among the four categories of income tax deductions, the benefits of special deductions are generally more regressive than the standard deductions or exemptions.

In Fig. 3, we calculate the ratio of tax benefits to household income for each category of deductions. The figures indicate that deductions' progressivity mostly comes from the poor households, specifically households in the first income decile. With low incomes and similar levels of tax benefits from standard deductions and exemptions, families in the first income decile on average could reduce their taxable incomes to zero. However, similar to our observations from Fig. 2, the progressivity of special deductions is less pronounced than other types of tax benefits, even if they are measured in relative terms as shares of a household's GI.

To compare how income tax deductions impact different types of families, we calculate ratios of tax benefits to household income based on family composition in Fig. 4. For exemptions and adjustment of BLE, the deductions provide a larger relief for families with dependents than those without. Standard and special deductions, on the other hand, do not differ much between taxpayers with or without dependents when we compare their tax benefits as shares of household income. Also, we find that since married households tend to have higher earnings than single-parent families, the benefits from exemptions and special deductions as shares of GI were thus more important for single taxpayers than their married counterparts.

Lastly, we calculate the distribution of tax benefits across income deciles for each itemized deduction and each special deduction. In Fig. 5, we present two series of numbers for each deduction. First, the usage rates of deductions, defined as the share of households that had claimed the deduction, are presented as a bar graph. Secondly, we show the distribution of tax benefits by income deciles as a line graph overlaid on the same chart. For each income decile, the height of the bar shows the percentage of households in the decile that used the deduction while the height of the line graph indicates the percentage of total tax benefits claimed by the families in the income decile.

Overall, itemized and special deductions were used at a much higher rate among households with higher incomes. Taxpayers with higher incomes tended to enjoy more benefits than households who were earning less. Deductions that were more closely tied to consumers' purchasing decisions especially demonstrated regressive patterns in usage rates and the benefit distributions. For example, more than half of the households (56\%) in the highest income decile used the deduction for cash donations in 2018 while less than $1 \%$ of households in the bottom three income deciles used the deduction. Moreover, households in the highest income decile claimed about three-fourths $(74.7 \%)$ of the total tax benefits from cash donations. Other deductions such as insurance or losses from property transactions also exhibit similar patterns. The deductions for savings and investment are surprisingly not as regressive as the 
(a)
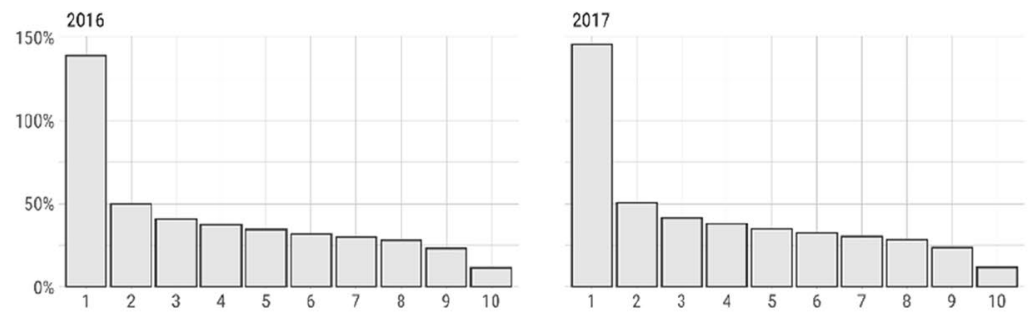

Ratio of Exemptions to Household Income

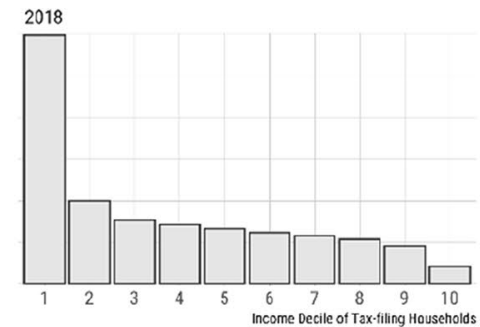

Ratio of Standard Deductions to Household Income

(b)
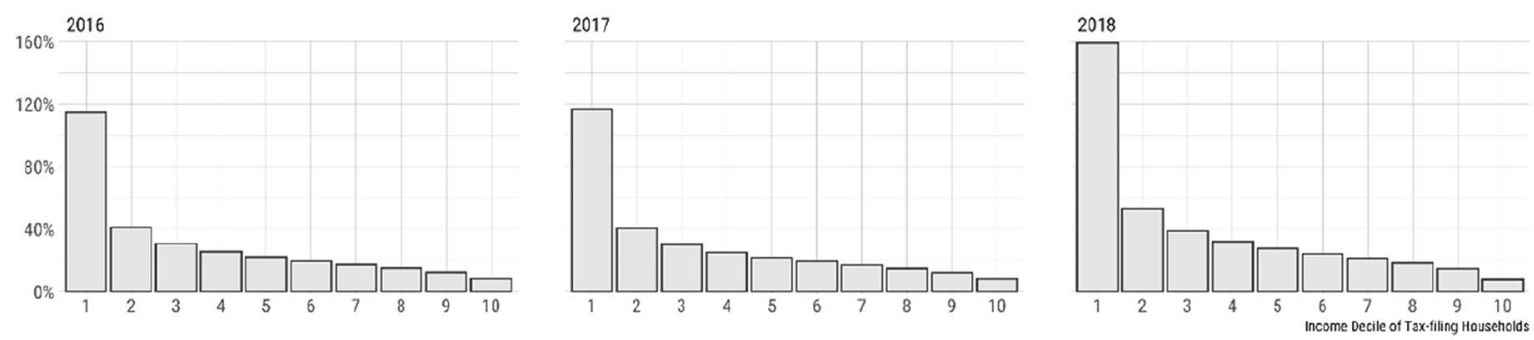

Ratio of Special Deductions to Household Income
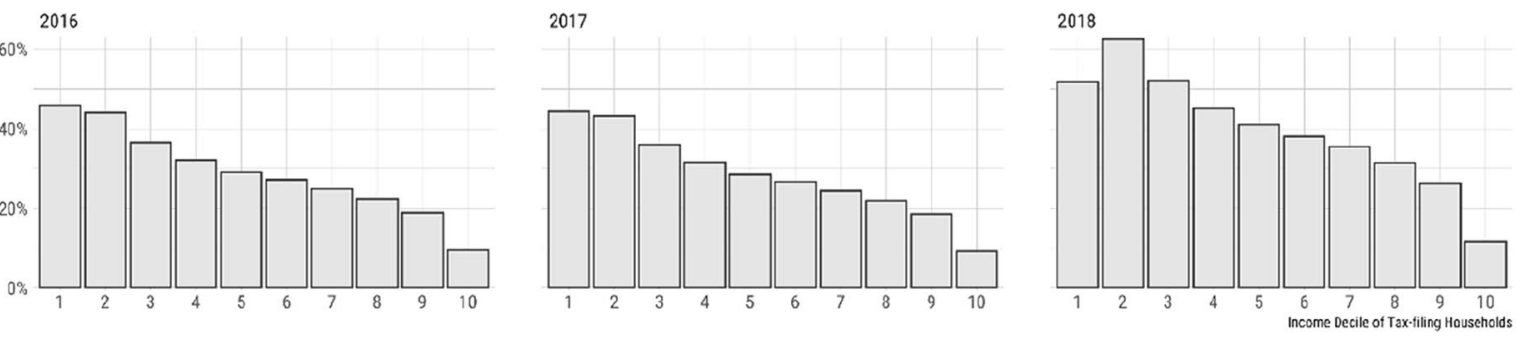

(d)

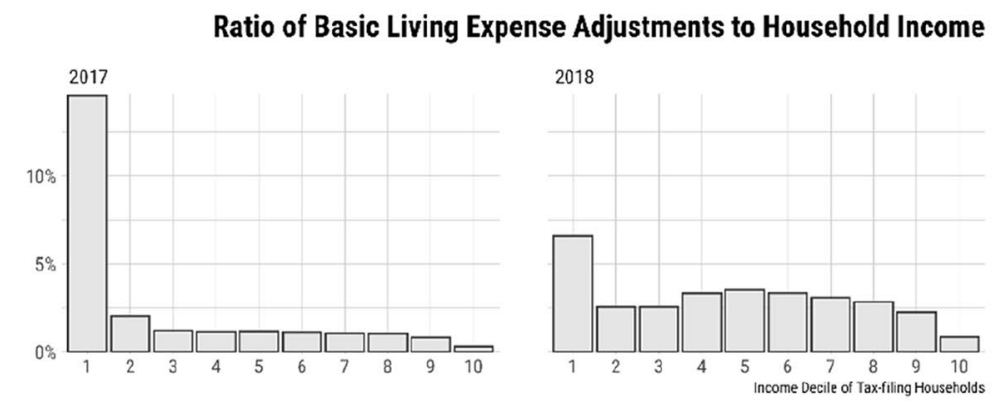

Fig. 3 Ratio of tax benefits to household income by income deciles, 2016-2018. Grouped data tables generated during the study to produce the charts are available from the authors upon request

aforementioned deductions. Similar to most OECD countries, Taiwan is in an era with historically low interest rates. As a result, most families have not utilized this deduction, and for those who did claim the deduction, its benefits, on average, were not significant. For example, in 2017, the average amount of savings interest that was deducted from household income was only NT\$52,523, well below the statutory maximum of NT\$270,000.

On the other hand, among the 14 itemized and special deductions, the deductions for wage income, disability, and education exhibited a more equal distribution of usage rates and benefits. Since these deductions offer a 
(a)

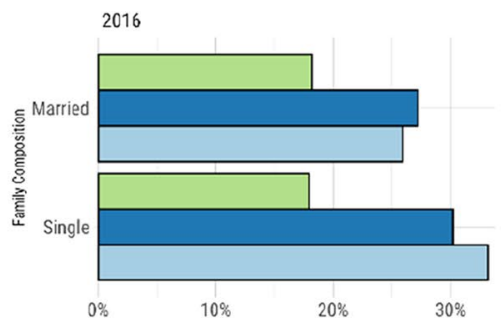

2017

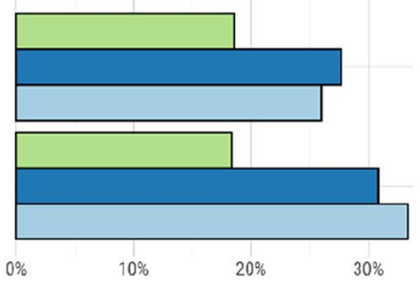

Exemption

2018

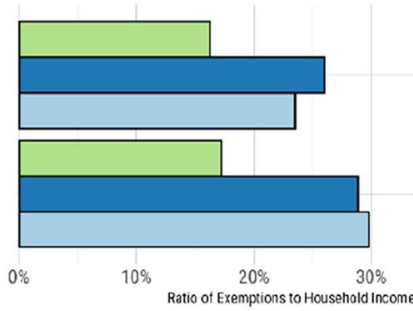

Standard Deductions

2018

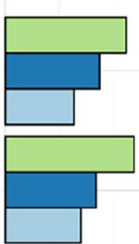

$\begin{array}{llll}0 \% & 20 \% & 40 \% & 60 \% \\ & \text { Ratio of Standard Deductions to Household Income }\end{array}$

(b)
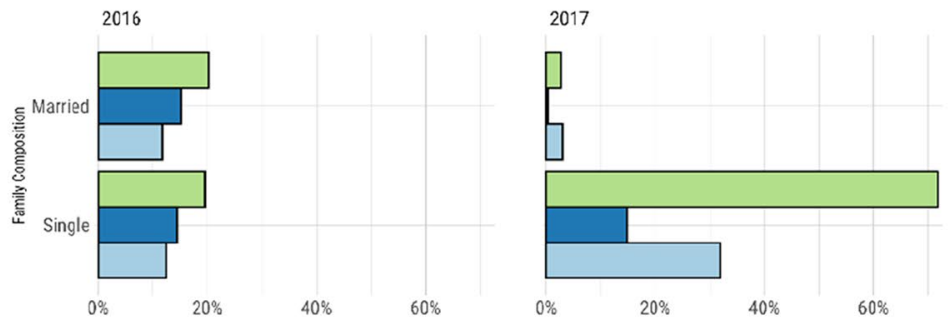

(c)

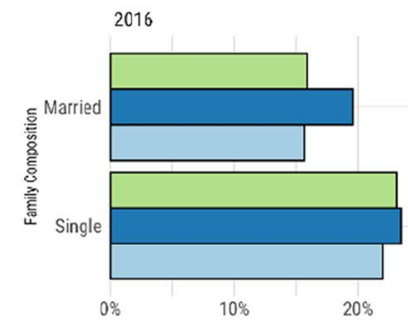

2017

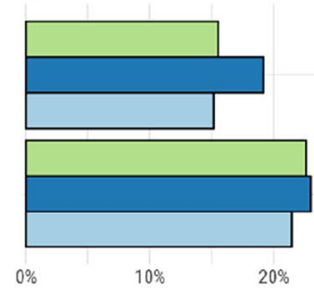

Special Deductions

2018

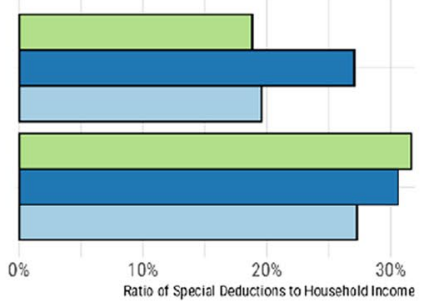

No Dependent.

Dependent (LA)

Dependent (Non-LA)

\section{Basic Living Expense Adjustments}

2017

(d)

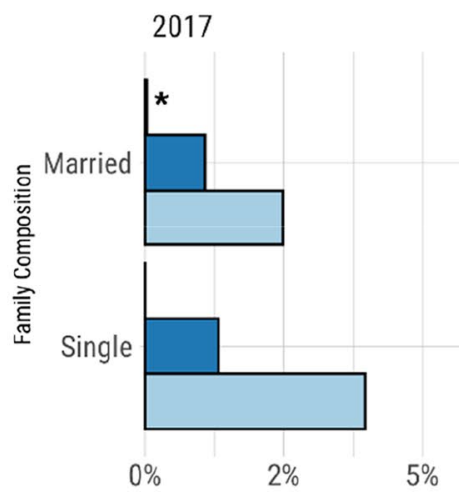

2018

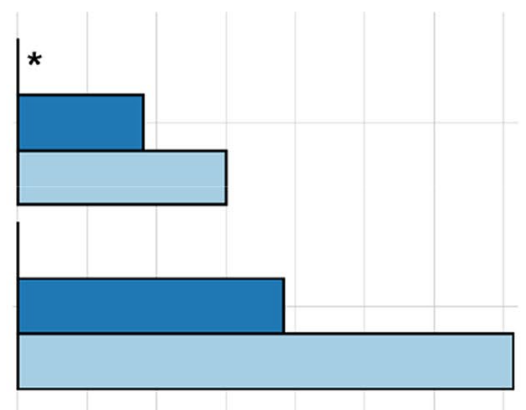

$0 \%$

$5 \%$

$8 \%$

Ratio of Basic Living Expense Adjustments to Household Income

No Dependent

Dependent (LA)

Dependent (Non-LA)
Fig. 4 Ratio of tax benefits to household income by family composition, 2016-2018. (1) LA refers to "lineal ascendant," which includes taxpayer and the spouse's parents, grandparents, and those in the direct line of antecedents. (2) *Indicates the ratio of tax benefits to household income is less than $0.1 \%$. (3) Grouped data tables generated during the study to produce the charts are available from the authors upon request 


\section{Usage Rates and Distribution of Benefits for Each Deduction}

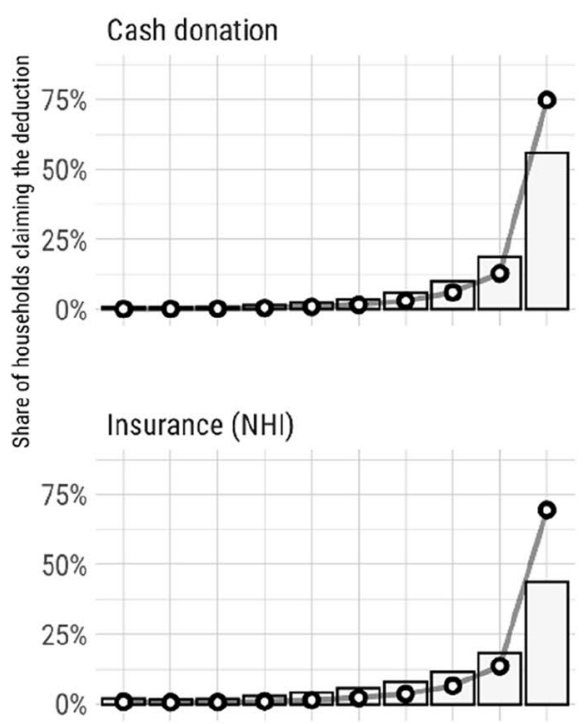

Mortgage interests

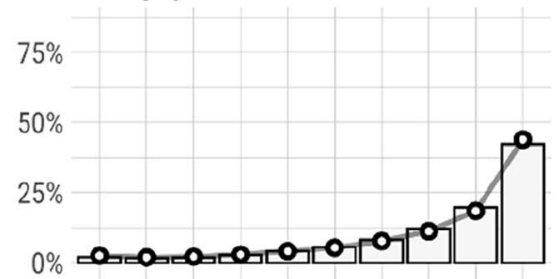

Loss from property transaction

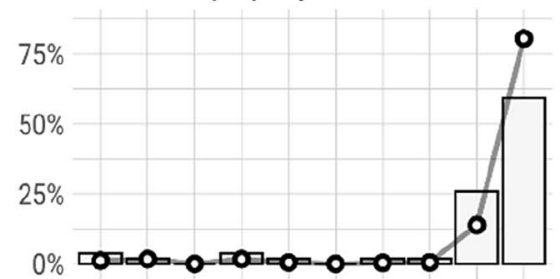

Education

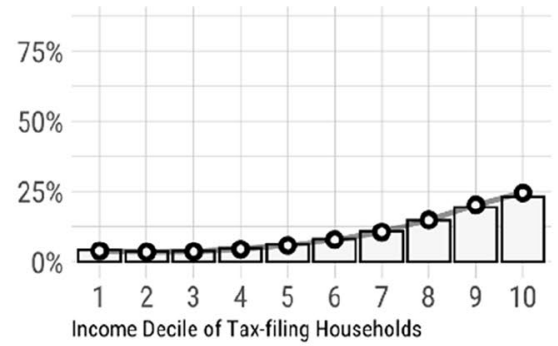

Non-cash donation

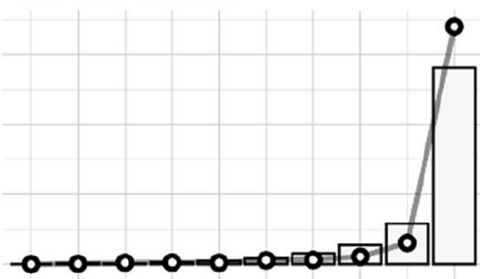

Medical and maternity expenses

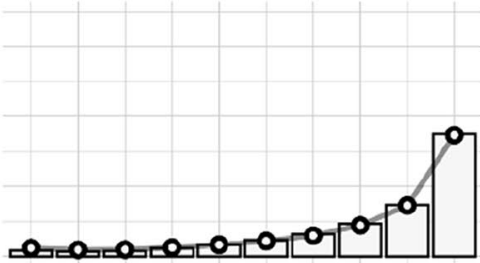

Rental expenditure

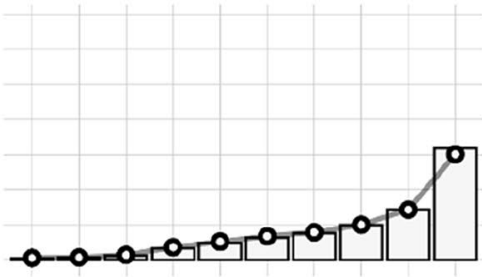

Savings and investment

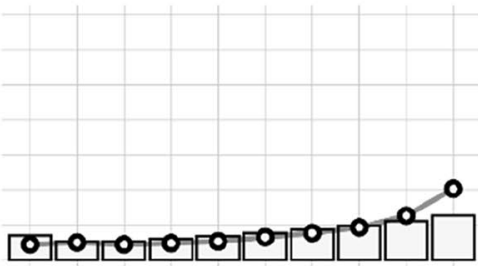

Preschooler

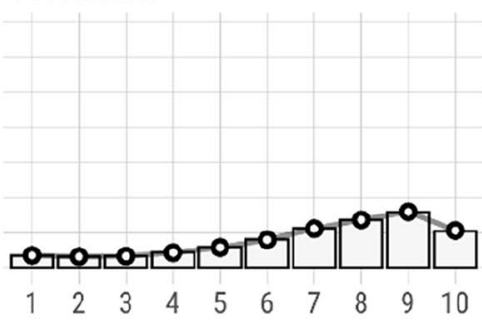

Insurance (non-NHI)

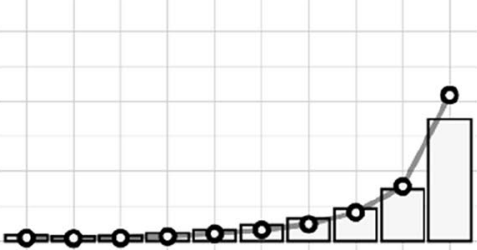

Disaster relief

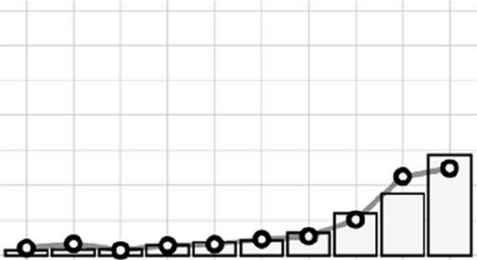

Salaries and wages

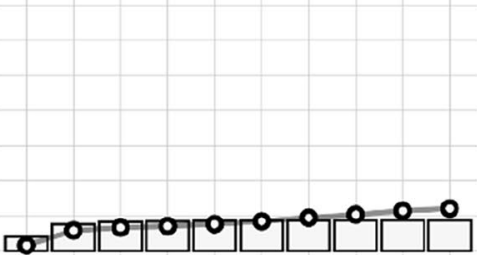

Physically or mentally challenged

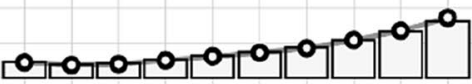

$\begin{array}{llllllllll}1 & 2 & 3 & 4 & 5 & 6 & 7 & 8 & 9 & 10\end{array}$

Percentage of Households Claiming the Deduction

Percentage of Total Benefits

- Claimed by Households in the Decile

Fig. 5 Usage rate and distribution of benefits for each itemized and special Deductions, 2018. Grouped data tables generated during the study to produce the charts are available from the authors upon request 
Table 10 Effect of tax reform for representative families

\begin{tabular}{|c|c|c|c|c|c|c|}
\hline \multirow[t]{2}{*}{ Tax dependents } & \multicolumn{3}{|l|}{ (i) } & \multicolumn{3}{|l|}{ (ii) } \\
\hline & \multicolumn{3}{|l|}{ None } & \multicolumn{3}{|c|}{$\begin{array}{l}- \text { Parents }(\text { one age }>70 \text { and the other age }<70) \\
- \text { One child }(\text { age }<5)\end{array}$} \\
\hline \multicolumn{7}{|l|}{ (a) Single taxpayer } \\
\hline Tax year & 2017 & 2018 & $\Delta$ & 2017 & 2018 & $\Delta$ \\
\hline Gross consolidated income & 640,000 & 640,000 & & 71,000 & 71,000 & \\
\hline Exemption & 88,000 & 88,000 & $0 \%$ & 396,000 & 396,000 & $0 \%$ \\
\hline Standard deductions & 90,000 & 120,000 & $+33 \%$ & 90,000 & 120,000 & $+33 \%$ \\
\hline Special deductions & 138,000 & 210,000 & $+52 \%$ & 163,000 & 330,000 & $+102 \%$ \\
\hline Basic living expenses & 166,000 & 171,000 & $+3 \%$ & 664,000 & 684,000 & $+3 \%$ \\
\hline Net consolidated income & 324,000 & 222,000 & $-102,000$ & 11,000 & 0 & $-11,000$ \\
\hline Tax liability & 16,200 & 11,100 & -5100 & 550 & - & -550 \\
\hline Marginal tax rate & $5 \%$ & $5 \%$ & & $5 \%$ & $0 \%$ & \\
\hline Effective tax rate & $2.53 \%$ & $1.73 \%$ & & $0.08 \%$ & $0.00 \%$ & \\
\hline \multirow[t]{2}{*}{ Tax dependents } & \multicolumn{3}{|l|}{ (iii) } & \multicolumn{3}{|l|}{ (iv) } \\
\hline & \multicolumn{3}{|c|}{$\begin{array}{l}\text { - Parent (age }>70) \\
\text { - Two children (both age }<5 \text { ) }\end{array}$} & \multicolumn{3}{|c|}{$\begin{array}{l}\text { - Parent }(\text { age }>70) \\
- \text { Two children (both age }<5 \text { ) }\end{array}$} \\
\hline \multicolumn{7}{|l|}{ (b) Couple taxpayers } \\
\hline Tax year & 2017 & 2018 & $\Delta$ & 2017 & 2018 & $\Delta$ \\
\hline Gross consolidated income & $1,270,000$ & $1,270,000$ & & $3,530,000$ & $3,530,000$ & \\
\hline Exemption & 484,000 & 484,000 & $0 \%$ & 484,000 & 484,000 & $0 \%$ \\
\hline Standard deductions & 180,000 & 240,000 & $+33 \%$ & 180,000 & 240,000 & $+33 \%$ \\
\hline Special deductions & 316,000 & 650,000 & $+106 \%$ & 316,000 & 650,000 & $+106 \%$ \\
\hline Basic living expenses & 830,000 & 855,000 & $+3 \%$ & 830,000 & 855,000 & $+3 \%$ \\
\hline Net consolidated income & 290,000 & 0 & $-290,000$ & $2,530,000$ & $2,136,000$ & $-394,000$ \\
\hline Tax liability & 14,500 & - & $-14,500$ & 382,400 & 292,600 & $-89,800$ \\
\hline Marginal tax rate & $5 \%$ & $0 \%$ & & $30 \%$ & $20 \%$ & \\
\hline Effective tax rate & $1.14 \%$ & $0.00 \%$ & & $10.83 \%$ & $8.29 \%$ & \\
\hline
\end{tabular}

Unless otherwise indicated, the numbers express the dollar value in TWD. In case (i), the single taxpayer's monthly wage is NT $\$ 45,000$. In case (ii), the single taxpayer's monthly wage is NT $\$ 50,000$. Both cases assume the taxpayer has NT $\$ 1,000,000$ in bank saving with annual interest rate of $1 \%$. In case (iii), the couple is jointly earning monthly income of NT $\$ 90,000$ with NT $\$ 1,000,000$ in bank savings. In case (iv), the couple is jointly earning monthly income of NT\$250,000 with NT\$3,000,000 in bank savings

fixed benefit amounts and their qualifications are based on personal traits or conditions instead of economic decisions, their distribution naturally did not differ much by household income.

\section{Effect of Reform for Families}

To demonstrate the effect of the reform on taxpayers, we calculate the reform's impact on four types of households: (i) a single-person household, (ii) a single taxpayer with dependents, (iii) a dual-income couple with dependents, and (iv) a high-income couple with dependents. Our analysis is summarized in Table 10. These results demonstrate that, while the reform can help reduce many tax-filing families' tax liabilities, most tax benefits generated from the expansion of exemptions and deductions would likely be enjoyed by families with higher incomes.

For single-person households, suppose the taxpayer (i) is earning approximately the average monthly income. ${ }^{18}$ The person would face the same marginal tax rates before and after the reform. However, due to the increase in exemptions and deductions, the person's tax payment was lowered by $31.5 \%$, which would bring down the person's effective tax rate from $2.53 \%$ in 2017 to $1.73 \%$ in 2018 .

\footnotetext{
18 The average monthly wage income in 2017 , which includes nonrecurring salary like bonuses or overtime pay, was NT\$54,796. Source: https://www.dgbas.gov.tw/ct.asp?xItem=43927\&ctNode= 5624. In our simulation, a worker's annual income is the sum of 12 months of wages and a year-end bonus that equals 2 months of wages. A worker with a monthly wage of NT $\$ 45,000$ in our table is can be said to have an average monthly income of NT $\$ 52,500$.
} 
On the other hand, suppose the single taxpayer (ii) is raising a 3-year-old child, and both of the person's elderly parents were claimed as dependents for tax-filing purposes. Before the reform, the taxpayer would pay very little tax (NT\$550) and faced a marginal tax rate of 5\%. After the reform, as the amounts for exemptions, the standard deduction, and the special deduction for preschool care had all increased in 2018, the amount of deductible income would actually exceed the person's GI. Consequently, the person would join the increasingly expanding group who were paying zero income tax. Nevertheless, the person's tax benefits were limited since the tax payments were only reduced by NT $\$ 550$ as a result of the reform.

In contrast, the expansion of exemptions and deductions was more beneficial for higher-income families. In case (iii), the couple is jointly earning a monthly income of NT $\$ 90,000$. Suppose they have two preschoolers and an elderly mother in the family. After the reform, their tax payments would be reduced from NT\$14,500 in 2017 to zero liability in 2018. The substantial cut in tax liability was the result of higher standard deductions and the special deduction for preschool care. After the reform, even some middleclass families would not need to pay an income tax since their incomes would be fully deducted.

Most tax benefits brought by the reform would likely go to upper-income families who were paying more taxes before the reform. Such a family's tax liability and marginal tax rate should be lowered as the expansion of deductions reduce the family's taxable income. Suppose a couple (iv) is earning a joint income of NT $\$ 250,000$ per month, putting them in the top $10 \%$ of the population in terms of household income. ${ }^{19}$ If they were also raising two children and had an elderly parent in the family, due to the increases in deductions and BLE, their tax payments would be lowered by NT $\$ 89,800$ in 2018, a 23.5\% reduction of their tax payment in 2017. More importantly, their marginal tax rate would be reduced from 30 to $20 \%$.

Overall, although many tax-filing families likely saw a reduction in their tax payment after the reform's expansion of exemptions and deductions, middle- and high-income families were likely the primary beneficiaries of the reform. Since lower-income families were paying little to no taxes prior to the reform, they would not have experienced noticeable changes in their tax liabilities. In addition, after the reform, we are seeing more middle-class families with zero tax liabilities as total deductions become more likely to exceed GI. If the government continues to implement similar

\footnotetext{
19 According to Taiwan's 2018 Survey of Family Income \& Expenditure, the threshold for the top household income decile is NT\$1,872,119. Source: https://win.dgbas.gov.tw/fies/doc/result/107/ a11/Year07.xls (accessed 3/1/2021).
}

income tax reforms that further expand the deductions, the tax benefits generated from these future reforms would become even more concentrated among upper-income families. Since they would face higher marginal tax rates before any reform, increases in deductions would enable them to reduce tax payments both by having smaller taxable incomes and by climbing down to a lower tax bracket.

\section{Conclusions}

In this study, we utilize tax-return microdata between 2016 and 2018 to analyze the redistributive effects of PIT. We first examine the overall redistributive effect of income taxation by showing that while the income tax has contributed to improving income distribution equality, its effects were limited and even declined slightly in recent years. We then focus on the distributional implications of exemptions and deductions, a major component of Taiwan's income tax reform implemented in 2018. We found the distribution of tax benefits to be generally regressive, especially among itemized and special deductions. While a deduction represents a larger share of household income for more impoverished families, wealthier households had claimed most of the tax benefits from various deductions. We also show that when the tax benefits are measured as shares of household income, the personal exemption and the adjustments of BLE provided more relief to households with dependents.

To further examine the relationship between income tax deductions and equality, we calculate and compare the usage rates and the benefit distributions for each itemized deduction and each special deduction. We found that itemized deductions and special deductions, in general, are claimed more frequently by households from higher income deciles. Deductions that are tied to discretionary purchasing decisions such as insurance and property transactions are naturally more regressive than other deductions. On the other hand, deductions determined by personal characteristics and capped at a fixed amount, such as deductions for wage income and disability, tend to be more equal. Even between households from both ends of the income spectrum, their benefits and usage rates did not vary substantially in the data. Overall, taxpayers with higher incomes also tended to enjoy more tax benefits from deductions than those in lower-income deciles.

Lastly, to illustrate the types of families that are more likely to benefit from the reform, we compare the changes in their tax payments between 2017 and 2018. We show that families who utilized more deductions and exemptions and families facing higher marginal tax rates would likely see a greater reduction in tax liability. In addition, their marginal tax rates are also more likely to be lowered since most poor to middle-income families were already in the lowest 
tax bracket prior to the reform. As a result, the income tax reform provided limited assistance to most families via the expansion of deductions, but the majority of tax expenditures were likely spent on higher-income families.

Although the Ministry of Finance touted the "Optimal Income Tax Adjustment" in 2018 as a major achievement of redistribution policy, its cost, lost revenue, and dwindling tax base were simply too great to bear. The arrival of the additional deduction in the adjustment of BLE exacerbated the off-balance problem. In the shadow of a worsening taxto-GDP ratio, Taiwan's tax base has dwindled significantly to only $48.87 \%$ of the tax-filing families paying taxes for 2018. The same phenomenon was seen elsewhere. China recently initiated a major PIT reform in which broadening deductions played an important role. However, simulation conducted by Zhan et al. (2019) shows that the deductioncentric reform not only dampens the overall PIT collection but also causes higher inequality (in terms of the after-tax Gini coefficient). Thus, in a broader reform-minded context, our analysis cautions the tax authority in Taiwan and equity pursuing policy makers in other countries not to prioritize an overarching short-term equity goal over long-term revenue stabilization. Phasing out or capping some of the itemized deductions such as donations and special deductions related to discretionary purchasing decisions looks to be a promising reform path toward improving equity and restoring revenue stability.

The current analysis is limited by the incomplete information on the household dynamics. Specifically, it only covers the households who filed tax returns. There is a significant discrepancy between the administrative data and the census data, which might be clue to a considerable number of "missing" households. The term of a tax-filing family in the administrative data may differ from the traditional definition of the household or family. The other prevailing methodology is employed in the Family Income and Expenditure Survey (FIES) by the Directorate-General of Budget, Accounting, and Statistics (DGBAS). The FIES defines a household as an economic unit that consists of individuals living in the same residence. To illustrate the difference, a (non-fulltime student in college) 20 -year-old adult child with taxable income will be treated as an independent taxing unit in the FIA's data, while the same individual would be accounted for in the same household with his or her parents in the FIES. The gap between total households and tax-filing households may reflect the size of the underground economy in which the incentive and easiness of tax evasion matter. This is an interesting and important line of research on our future agenda.

Acknowledgements We are indebted to the Fiscal Information Agency and Taxation Administration Agency of the Ministry of Finance, R.O.C. (Taiwan) for the assistance on the access of the administrative tax return data. This research was supported by the Ministry of Science and Technology (MOST), Taiwan (Grant No. MOST 109-2410-H-305049-MY2). We would also like to thank the anonymous reviewers for their constructive comments on the manuscript. The views and opinions expressed in this article are those of the authors and do not necessarily reflect the official policy or position of the aforementioned agencies.

\section{Declarations}

Conflict of interest All authors declare that they have no conflict of interest.

\section{References}

Aronson, J. R., \& Lambert, P. J. (1994). Decomposing the Gini coefficient to reveal the vertical, horizontal, and reranking effects of income taxation. National Tax Journal, 47(2), 273-294.

Barbetta, G. P., Pellegrino, S., \& Turati, G. (2018). What explains the redistribution achieved by the Italian personal income tax? Evidence from administrative data. Public Finance Review, 46(1), 7-28. https://doi.org/10.1177/1091142116651488

Bird, R. M., \& Zolt, E. M. (2005). The limited role of the personal income tax in developing countries. Journal of Asian Economics, 16(6), 928-946. https://doi.org/10.1016/j.asieco.2005.09. 001

Bourassa, S. C., \& Yin, M. (2008). Tax deductions, tax credits and the homeownership rate of young urban adults in the United States. Urban Studies, 45(5-6), 1141-1161. https://doi.org/10.1177/ 0042098008089981

Branco, R., \& Costa, E. (2018). The golden gge of tax expenditures: Fiscal welfare and inequality in Portugal (1989-2011). New Political Economy. https://doi.org/10.1080/13563467.2018.1526264

Burkhauser, R. V., Feng, S., Jenkins, S. P., \& Larrimore, J. (2012). Recent trends in top income shares in the United States: Reconciling estimates from March CPS and IRS tax return data. Review of Economics and Statistics, 94(2), 371-388. https://doi.org/10. 1162/REST_a_00200

Burman, L. E., Geissler, C., \& Toder, E. J. (2008). How big are total individual income tax expenditures, and who benefits from them? American Economic Review, 98(2), 79-83. https://doi.org/10. 1257/aer.98.2.79

Burman, L. E., \& Phaup, M. (2012). Tax expenditures, the size and efficiency of government, and implications for budget reform. Tax Policy and the Economy, 26(1), 93-124. https://doi.org/10. 1086/665504

Cauble, E. (2017). Itemized deductions in a high standard deduction world. Stanford Law Review Online, 70, 146. https://doi.org/10. 2139/ssrn.3096620

Chu, C. C., Chou, T., \& Hu, S. C. (2015). Top Incomes in Taiwan, 1977-2013. WID. world Working Paper, 2015/6.

Chu, Y.-W.L., \& Lin, M.-J. (2020). Intergenerational earnings mobility in Taiwan: 1990-2010. Empirical Economics, 59(1), 11-45. https://doi.org/10.1007/s00181-019-01637-0

Department of the Treasury. (2010). Economics of taxation. https:// www.treasury.gov/resource-center/faqs/Taxes/Pages/economics. aspx

Feldstein, M., \& Clotfelter, C. (1976). Tax incentives and charitable contributions in the United States. A microeconometric analysis. Journal of Public Economics, 5(1-2), 1-26. https://doi.org/10. 1016/0047-2727(76)90058-X

Gastwirth, J. L. (1972). The estimation of the Lorenz curve and gini index. The Review of Economics and Statistics, 54(3), 306-316. https://doi.org/10.2307/1937992 
González-Chapela, J., \& Ortega-Lapiedra, R. (2021). Reform of the personal income tax in Spain: Effects on internal mobility of the unemployed. Journal of Family and Economic Issues, 42(1), $166-181$.

Hines, J. R., Jr., \& Summers, L. H. (2009). How globalization affects tax design. Tax Policy and the Economy, 23(1), 123-158. https:// doi.org/10.1086/597056

Jann, B. (2016). Estimating Lorenz and concentration curves. The Stata Journal, 16(4), 837-866. https://doi.org/10.1177/1536867X16 01600403

Jensen, J. E. (1954). Rationale of the medical expense deduction. National Tax Journal, 7(3), 274.

Kahn, C.H. (1960). Personal deductions in the federal income tax. Princeton University Press.

King, M. A. (1983). Welfare analysis of tax reforms using household data. Journal of Public Economics, 21(2), 183-214. https://doi. org/10.1016/0047-2727(83)90049-X

Lambert, P. (2001). The distribution and redistribution of income. Manchester University Press.

Lee, Y.-F.L. (2008). Economic growth and income inequality: The modern Taiwan experience. Journal of Contemporary China, 17(55), 361-374. https://doi.org/10.1080/10670560701809577

Lien, H.-M., Tseng, C.-H., Yang, T.-T., Han, H.-W., \& Lo, K.-T. (2021). Wealth distribution in Taiwan 2004-2014: Evidence from the individual wealth register data. Taiwan Economic Review, 49(1), 77-130. https://doi.org/10.6277/TER.202103_49(1).0003

Lorenz, M. O. (1905). Methods of measuring the concentration of wealth. Publications of the American Statistical Association, 9(70), 209-219. https://doi.org/10.2307/2276207

Mirrlees, J., \& Adam, S. (2011). Tax by design: The Mirrlees review. Oxford University Press.

Moriguchi, C., \& Saez, E. (2008). The evolution of income concentration in Japan, 1886-2005: Evidence from income tax statistics. Review of Economics and Statistics, 90(4), 713-734. https://doi. org/10.1162/rest.90.4.713

O'donnell, O., Van Doorslaer, E., Wagstaff, A., \& Lindelow, M. (2007). Analyzing health equity using household survey data: A guide to techniques and theirimplementation. The World Bank.

OECD. (2016). Tax policy reforms in the OECD 2016. OECD Publishing. https://doi.org/10.1787/9789264260399-en

OECD. (2017). Tax policy reforms 2017: OECD and selected partner economies. OECD Publishing. https://doi.org/10.1787/97892 64279919-en

OECD. (2018). Tax policy reforms 2018: OECD and selected partner economies. OECD Publishing. https://doi.org/10.1787/97892 64304468-en

OECD. (2019a). Tax policy reforms 2019: OECD and selected partner economies. OECD Publishing. https://doi.org/10.1787/da56c 295-en

OECD. (2019b). Under pressure: the squeezed middle class. OECD Publishing.

OECD. (2020). Tax and fiscal policy in response to the coronavirus crisis: strengthening confidence and resilience. OECD.

Pechman, J. A. (1990). The future of the income tax. The American Economic Review, 80(1), 1-20.

Pfähler, W. (1990). Redistributive effect of encome taxation: Decomposing tax base and tax rates effects. Bulletin of Economic Research, 42(2), 121-129. https://doi.org/10.1111/j.1467-8586. 1990.tb00295.x

Pigou, A. C. (1920). The economics of welfare. Macmillan.

Piketty, T., \& Saez, E. (2003). Income inequality in the United States, 1913-1998. The Quarterly Journal of Economics, 118(1), 1-41. https://doi.org/10.1162/00335530360535135

Sommer, K., \& Sullivan, P. (2018). Implications of US tax policy for house prices, rents, and homeownership. American Economic Review, 108(2), 241-274. https://doi.org/10.1257/aer.20141751
Tanzi, V. (2002). Globalization and the future of social protection. Scottish Journal of Political Economy, 49(1), 116-127. https:// doi.org/10.1111/1467-9485.00224

Taussig, M. K. (1967). Economic aspects of the personal income tax treatment of charitable contributions. Natioanl Tax Journal, 20(1), $1-19$.

Tsai, I.-C., \& Peng, C.-W. (2011). Bubbles in the Taiwan housing market: The determinants and effects. Habitat International, 35(2), 379-390.

Wu, D.-K., \& Chen, J. (2018). An estate tax data analysis of wealth inequality and wealth composition in Taiwan. Taiwan Economic Review, 46(4), 523-567. https://doi.org/10.6277/TER.201812_ 46(4).0002

Yitzhaki, S., \& Schechtman, E. (2013). The Lorenz curve and the concentration curve. The Gini methodology: A primer on a statistical methodology (pp. 75-98). Springer.

Zhan, P., Li, S., \& Xu, X. (2019). Personal income tax reform in China in 2018 and its impact on income distribution. China \& World Economy, 27(3), 25-48.

Publisher's Note Springer Nature remains neutral with regard to jurisdictional claims in published maps and institutional affiliations. 